\title{
Zinc deficiency induces behavioral alterations in the tail suspension test in mice. Effect of antidepressants
}

\author{
Katarzyna Młyniec ${ }^{1,2}$, Gabriel Nowak ${ }^{1,2}$ \\ ${ }^{1}$ Department of Pharmacobiology, Faculty of Pharmacy, Jagiellonian University Medical College, Medyczna 9 , \\ PL 30-688 Kraków, Poland \\ ${ }^{2}$ Laboratory of Trace Elements Neurobiology, Department of Neurobiology, Institute of Pharmacology, \\ Polish Academy of Sciences, Smętna 12, PL 31-343 Kraków, Poland \\ Correspondence: Gabriel Nowak, e-mail: nowak@if-pan.krakow.pl
}

\begin{abstract}
:
Background: Recently, experimental zinc deficiency has been correlated with depression-like alterations in rodents.

Methods: In the first part of present study, the time course of zinc deficient diet induced alterations in the tail suspension test (TST) in mice was investigated. In the second part, the effect of imipramine and escitalopram in control and zinc-deprived for 3 weeks mice was examined in the TST.

Results: A 4- and 10-week administration of a Zn-deficient diet enhanced the immobility time in the TST (by 20\% and 57\%, respectively). By contrast, a 2-week period of a zinc deficient diet effected the reduction (by $24 \%$ ) of the immobility time. Moreover, a 2- and 4-week (but not 10-week) of a Zn-deficient diet resulted in the reduction of the body weight (by $37 \%$ and $18 \%$, respectively). These results indicate the developing response to zinc deficiency induced by a zinc-deficient diet. The antidepressant-like effect (reduction in the immobility time) of both drugs was significantly reduced in zinc-deprived mice, which suggests treatment-resistance induced by zinc deprivation.

Conclusion: Zinc deprivation induces "pro-depressive" behavior and alters antidepressant efficacy.
\end{abstract}

Key words:

zinc deficiency, tail suspension test, body weight, depression, antidepressants

\section{Introduction}

Zinc is an important trace element in all living organisms and plays an important role in DNA replication, transcriptions and protein synthesis, thus influencing cell division and differentiation [22]. Its deficiency retards the growth of humans and animals and also affects brain function $[22,38,43,49]$. Throughout the previous decade, there has been some evidence sug- gesting a link between zinc and depression $[10,16$, 34, 36]. Experiments conducted on animals showed antidepressant zinc actions in the forced swim test (FST) $[7,8,17,20]$ and tail suspension test (TST) $[4$, 20] and, moreover, zinc reversed the depressive behavior caused by the organophosphate malathion [1] chronic mild stress [29], chronic unpredictable stress (CUS) [3] and olfactory bulbectomy [17]. Furthermore, zinc can enhance the action of antidepressants in the FST, TST and CUS $[3,4,7,20,32]$. 
Up to $50 \%$ of the population is thought to have inadequate levels of zinc in their blood and this is common worldwide in both developed and underdeveloped countries [2], and, in turn, may be related to depression. Most clinical studies demonstrated a low serum zinc level in patients suffering from major/unipolar depression compared to a non-depressed control, while no alterations were also noticed (e.g., [11, 13, 24]). A lower serum zinc level also accompanied antepartum and postpartum depressive symptoms [50]. Moreover, the clinical efficacy of pharmacotherapy was positively correlated with a rise in the serum zinc level $[12,24]$. Some clinical studies have showed that zinc supplementation may enhance antidepressant therapy [15, 21, 23].

Recently, it was demonstrated that zinc deficiency leads to the development of some depression-like alterations $[44,45,48,49]$. To establish the proper time to assess depression-like behavior induced by zinc deficiency in mice, the first part of present study examined the time course of the effect of administration of a zinc deficient diet on behavior in TST and on their body weight. In the second part, the effect of imipramine and escitalopram administration in control and zinc-deprived mice on behavior in TST was examined.

\section{Materials and Methods}

\section{Animals and treatment}

Male CD-1 mice ( $\sim 16 \mathrm{~g})$ were housed under standard laboratory conditions with a natural day-night cycle, temperature $22 \pm 2{ }^{\circ} \mathrm{C}$ and humidity $55 \pm 5 \%$ and had access to food and water ad libitum. Each experimental group consisted of 6-8 animals. All procedures were conducted according to the National Institute of Health Animal Care and Use Committee guidelines, which were approved by the Ethical Committee of the Jagiellonian University Medical College, Kraków.

Control (33.5 mg Zn/kg) and zinc deficient (0.2 mg $\mathrm{Zn} / \mathrm{kg}$ ) diets were purchased from MP Biomedicals (France). In the first part of experiment, mice were assigned to one of eight different groups according to the duration of the diet administration $(2,3,4$ or 10 weeks). In the second part, mice were allocated to control and zinc-deficient diet for 3 weeks and then received acute administration of vehicle or antidepressant.
After 3 weeks of control or zinc-deficient diet administration, vehicle, imipramine, $30 \mathrm{mg} / \mathrm{kg}$ (Sigma, Germany) or escitalopram, $4 \mathrm{mg} / \mathrm{kg}$ (Lundbeck, Denmark) was intraperitoneally (ip) injected $0.5 \mathrm{~h}$ before the test. Control animals received $0.9 \% \mathrm{NaCl}$ solution (vehicle). All solutions were administered at a volume of $10 \mathrm{ml} / \mathrm{kg}$.

\section{TST}

The TST described by Steru et al. [30] is one of the most widely used behavioral paradigms for assessing antidepressant-like activity in mice. The mice used in our study were securely fastened with medical adhesive tape by the tip of the tail to a flat surface and suspended for $6 \mathrm{~min}$ approximately $30 \mathrm{~cm}$ below the surface. The total time of immobility was measured during the entire $6 \mathrm{~min}$ of the testing session. Immobility was defined when the animals hung passively without limb movement and was scored manually.

\section{Locomotor activity test}

The locomotor activity of the mice was measured with photoresistor actometers (circular cages, diameter $25 \mathrm{~cm}$, two light beams). The animals were individually placed in an actometer. Activity was measured during $6 \mathrm{~min}$. The number of crossings of the light beams by the mice was then recorded as the locomotor activity.

\section{Data analysis}

The data are presented as the mean \pm SEM. Comparisons between control and experimental groups were performed by the Students $t$-test; $\mathrm{p}<0.05$ was considered significant.

\section{Results}

Body weight of the mice at the beginning of the experiment (before any diet) was $16.0 \pm 2.2 \mathrm{~g}$. There was a significant reduction in body weight in the zinc-deficient animals compared to the control by $37 \%[\mathrm{t}(14)=7.271, \mathrm{p}<0.001]$ after 2 weeks and by $18 \%[\mathrm{t}(14)=6.760, \mathrm{p}<0.001]$ after 4 weeks of diet (Tab. 1). There was no difference between zinc- 
Tab. 1. The influence of 2, 4 and 10 weeks' administration of a zinc deficient diet on the body weight $(\mathrm{g})$ of mice. Values are the means \pm SEM of 7-8 animals per group; ${ }^{*} \mathrm{p}<0.05$ vs. proper control (Student $t$-test)

\begin{tabular}{lcc}
\hline & Control & Zinc deficiency \\
\hline 2 weeks & $33.6 \pm 1.2$ & $21.3 \pm 1.2^{*}$ \\
4 weeks & $41.8 \pm 0.9$ & $34.3 \pm 0.7^{*}$ \\
10 weeks & $50.1 \pm 2.4$ & $52.7 \pm 0.9$ \\
\hline
\end{tabular}

deficient animals compared to control after 10 weeks $[\mathrm{t}(12)=1.017, \mathrm{p}=0.3293]($ Tab. 1).

The effects of zinc deficiency on the total duration of the immobility time in mice are shown in Figure 1. The zinc deficient diet administered for 2 weeks significantly (by $24 \%[\mathrm{t}(13)=4.062, \mathrm{p}=0.0013]$ ) reduced the immobility time in the test (Fig. 1A). The zinc deficient diet administered for 4 weeks significantly (by $20 \%[\mathrm{t}(12)=2.733, \mathrm{p}=0.0182]$ ) increased the immobility time in the test (Fig. 1B). The zinc deficient diet administered for 10 weeks significantly (by $57 \%[\mathrm{t}(12)=3.324, \mathrm{p}=0.0061]$ ) increased the immobility time in the test (Fig. 1C).

The effects of zinc deficiency on the total duration of the immobility time in mice after a 3-week zinc deficient diet and acute antidepressants administration are shown in Figure 2. There were no significant changes $[t(11)=0.8359, p=0.4210]$ after zinc deficient diet administered for 3 weeks in the immobility time in the test (Fig. 2A). Imipramine administration to zinc-deprived mice significantly (by $123 \%,[\mathrm{t}(12)=$ $3.904, \mathrm{p}=0.0021]$ ) increased the immobility time compared to imipramine effect in control, vehicle treated animals (Fig. 2B). Similarly, escitalopram administration to zinc-deprived mice significantly (by $96 \%,[t(12)=2.309, \mathrm{p}=0.0497])$ increased the immobility time compared to escitalopram effect in control animals (Fig. 2C). Both, imipramine and escitalopram were able to reduce the immobility time in control and in zinc-deficient mice, but the \% of reduction was higher in control mice, which may indicate a treatment-resistance induced by zinc deprivation.

No effects of zinc deficiency $+/$ - antidepressant treatments on locomotor activity in all examined time periods were observed (data not shown).

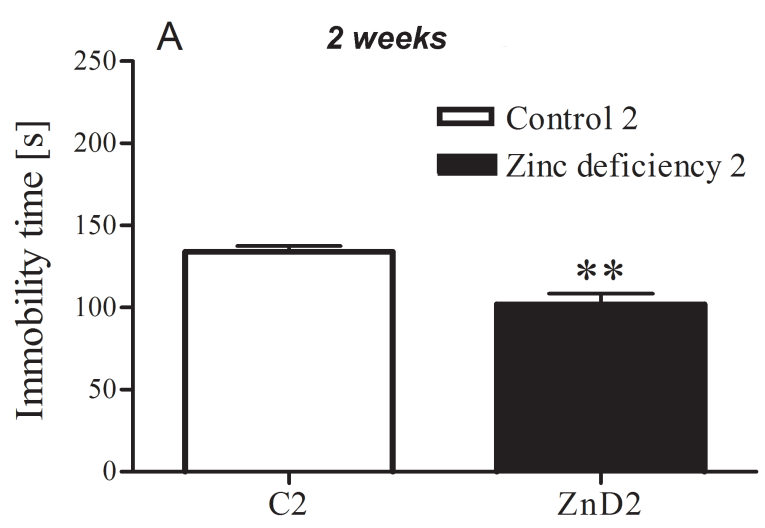

B 4 weeks
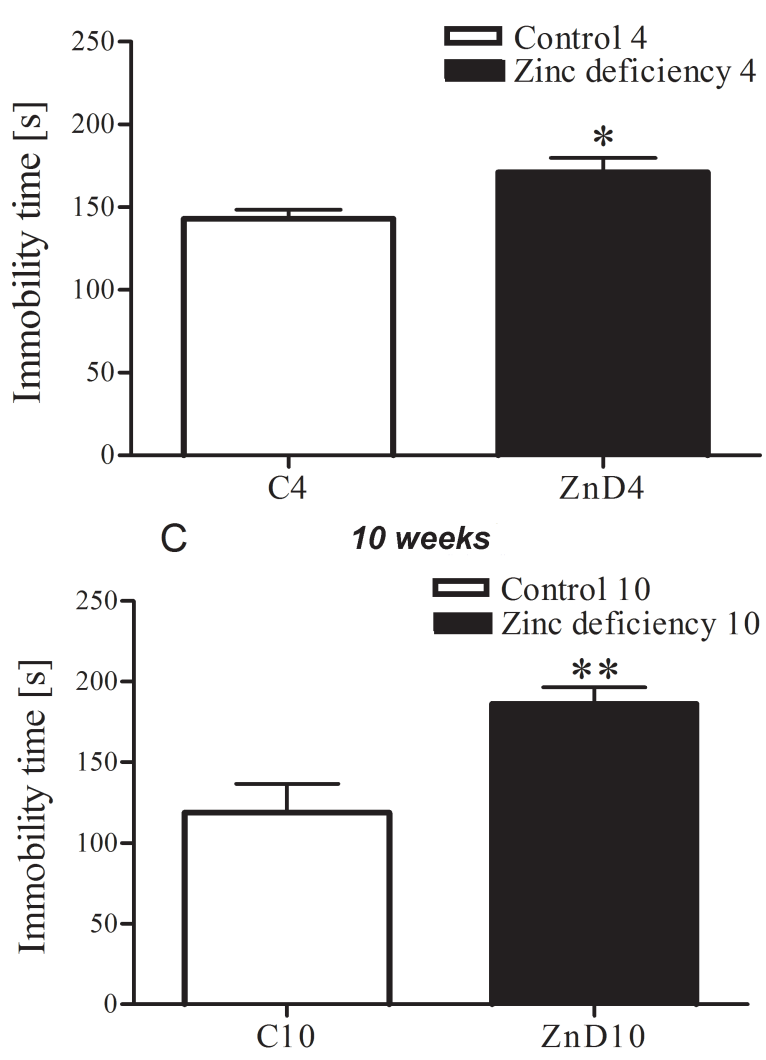

Fig. 1. The influence of $2(\mathbf{A}), 4(\mathbf{B})$ and 10 (C) weeks' administration of a zinc deficient $(\mathrm{ZnD})$ diet on immobility time in the tail suspension test (TST) in mice. Values are the means \pm SEM of $7-8$ animals per group; ${ }^{*} p<0.05,{ }^{* *} p<0.01$ vs. proper control (Student $t$-test)

\section{Discussion}

Zinc exhibits antidepressant-like properties in tests and models of depression and augments the activity of antidepressants in some behavioral paradigms [3, 4, 7, $8,17,20,29,32,37]$. Moreover, augmentation of the 


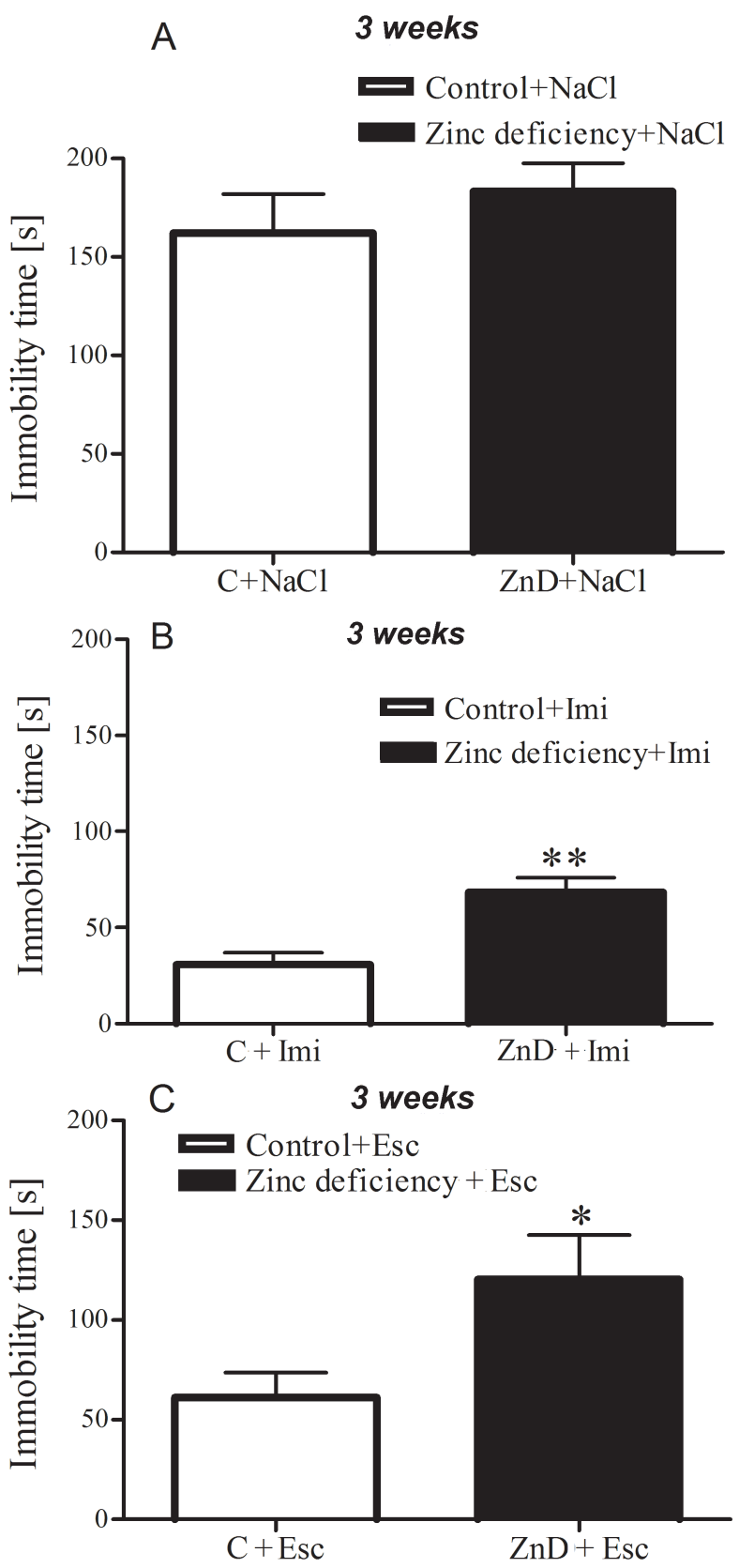

Fig. 2. The influence of 3-week zinc deficient $(\mathrm{ZnD})$ diet and acute $\mathrm{NaCl}(0.9 \%)$ (A), imipramine (Imi) (B) or escitalopram (Esc) (C) administration on immobility time in the tail suspension test (TST) in mice. Values are the means \pm SEM of 6-7 animals per group; ${ }^{*} p<$ $0.05,{ }^{* *} p<0.01$ vs. proper control diet (Student $t$-test)

efficacy of antidepressants by zinc co-treatment was demonstrated in the therapy of depressive disorder $[15,21,23]$.

At first, we observed a significantly lower body weight gained in groups that received a zinc deficient diet for 2 and 4 weeks yet not at 10 weeks when com- pared to the control. The previous study suggests that zinc deficiency causes anorexia [9]. However, decreased food intake seems not to be the cause of depression-like behavior, because the immobility time in FST was found to be significantly higher in zincdeficient but not pair-fed rats [48]. Our results indicate that lower body weight does not correlate with depressive behavior, especially as evident after 10 weeks of a zinc deficient diet. After this period of time, there were no differences in body weight between the groups, but significant differences in immobility time, so the notion that the anorexia induced by a zinc deficient diet is the cause of depressive-like behavior should be eliminated.

In order to establish the role of zinc deficiency in depression, several studies used a special low zinc diet. Whittle et al. [49] showed that dietary zincdeficiency in mice, with up to $40 \%$ of the recommended daily intake requirement, caused a prodepressive phenotype in the FST and TST. The present results indicate differences during the time course zinc-deficiency induced effect in the TST. Animals subjected to 2 weeks of a zinc deficient diet exhibit anti-depressive behavior, while those which were kept on a zinc deficient diet for 4 or 10 weeks demonstrated pro-depressive behavior. The locomotor activity did not participate in these above mentioned behavioral alterations in the TST (no change in locomotor activity was demonstrated). The differences between 2 and 4-10 weeks can be linked with the concentration of zinc in the brain, as described by Takeda and co-workers in young rats; and it is possible that the same mechanism is applicable to young mice. These data indicate that extracellular and vesicular zinc in the hippocampus did not significantly change in young rats after 2-week zinc deprivation $[40,42]$, but it was reduced in young rats after 4weeks zinc deprivation ( $30 \%$ of that of control rats) $[39,41]$. On the other hand, Tamano et al. [44] and Watanabe et al. [48] demonstrated pro-depressive behavior (an increase in immobility time) in the FST after 2-week zinc deprivation in young rats. It is possible that the differences are due to another animal species or differences in the zinc concentration of the $\operatorname{diet}(52.8 \mathrm{mg} \mathrm{Zn} / \mathrm{kg}$ for the control and $0.37 \mathrm{mg} \mathrm{Zn} / \mathrm{kg}$ for the zinc deficiency). The antidepressant activity in the TST after 2 weeks of zinc deprivation can be explained as a compensation mechanism. It is possible that in the first few days, metallothioneins release more zinc in deficiency than in the control animals. 
Metallothioneins are able to bind up to seven atoms of zinc temporarily, and therefore, bind zinc when it is in excess in the cytoplasm plus release it when there is a shortage [46]. Yeiser et al. [51] observed higher free $\mathrm{Zn}^{2+}$ and metallothionein 3 mRNA accumulation at the site of injury in adult rat brains. Moreover, amount of zinc contained in the diet and period of time of its administration before feeding animals with zincdeficient diet may be important factors in zincdeficiency-induced alterations in zinc homeostasis (our unpublished data [18]).

The antidepressant action of zinc is related to modulation of the glutamatergic system, but mostly to the inhibition of NMDA receptor activity, and can fit the NMDA/glutamate hypothesis of depression [25-28, 33-36].

There is a link between zinc deficiency and glutamate/GABA-ergic/glucocorticoid systems. Zinc deficiency was accompanied by an enhanced release of glutamate and reduction in GABA concentration as demonstrated by in vivo microdialysis experiments $[19,42]$. Pro-depressive behavior in zinc deficiency may be associated with hyperactivation of the hypothalamic-pituitary-adrenal axis and enhanced activity of the glutamatergic system, as observed in depressed patients and in experimental zinc deficiency $[6,31,42,48,52]$. Stress, which induces glucocorticoids secretion, contributes to increasing the extracellular levels of glutamate [5, 14, 47].

The antidepressant-like effect (reduction in the immobility time in the TST) of imipramine and escitalopram was significantly reduced in mice fed with zinc-deficient diet for 3 weeks, which suggest treatment-resistance to the action of these drugs induced by zinc deprivation. Involvement of zinc in the treatment resistant patients was suggested by previous clinical studies $[12,23,24]$ and experimental zinc deficiency study [45].

In summary, the present results indicate that zinc deprivation induced (after an initial period of "antidepressive" behavior) "pro-depressive" behavior in the TST in mice. Thus, the proper timing of zinc deprivation should be recognized before someone can evaluate the validity of zinc deprivation as a model of depression. Moreover, the antidepressant-like effect of examined antidepressants (imipramine, escitalopram) in zinc-deprived for 3 weeks animals were attenuated, which suggests treatment-resistance induced by zinc deprivation.

\section{Acknowledgments:}

The authors thank Lundbeck (Denmark) for the generous gift of escitalopram. This study was partially supported by the grant POIG.01.01.02-12-004/09-00 and Funds for Statutory Activity of the Institute of Pharmacology, Polish Academy of Sciences in Kraków and Jagiellonian University Medical College in Kraków, Poland.

\section{References:}

1. Brocardo PS, Assini F, Franco JL, Pandolfo P, Müller YM, Takahashi RN, Dafre AL, Rodrigues AL: Zinc attenuates malathion-induced depressant-like behavior and confers neuroprotection in the rat brain. Toxicol Sci, 2007, 97, 140-148.

2. Brown KH, Wuehler SE, Peerson JM: The importance of zinc in human nutrition and estimation of the global prevalence of zinc deficiency. Food Nutr Bull, 2001, 22, $113-125$.

3. Cieślik K, Klenk-Majewska B, Danilczuk Z, Wróbel A, Łupina T, Ossowska G: Influence of zinc supplementation on imipramine effect in a chronic unpredictable stress (CUS) model in rats. Pharmacol Rep, 2007, 59, $46-52$.

4. Cunha MP, Machado DG, Bettio LEB, Capra JC, Rodrigues ALS: Interaction of zinc with antidepressants in the tail suspension test. Prog Neuropsychopharmacol Biol Psychiatry, 2008, 32, 1913-1920.

5. Danbolt NC: Glutamate uptake. Prog Neurobiol, 2001, $65,1-105$.

6. Jokinen J, Nordström P: HPA axis hyperactivity and attempted suicide in young adult mood disorder inpatients. J Affect Disord, 2009, 116, 117-120.

7. Kroczka B, Brański P, Pałucha A, Pilc A, Nowak G: Antidepressant-like properties of zinc in rodent forced swim test. Brain Res Bull, 2001, 55, 297-300.

8. Kroczka B, Zięba A, Dudek D, Pilc A, Nowak G: Zinc exhibits an antidepressant like effect in the forced swimming test in mice. Pol J Pharmacol, 2000, 52, 403-406.

9. Levenson CW: Zinc regulation of food intake: new insights on the role of neuropeptide Y, Nutr Rev, 2003, 61, 247-249.

10. Levenson CW: Zinc: the new antidepressant? Nutr Rev, 2006, 64, 39-42.

11. Maes M, D'Haese PC, Scharpe S, D’Hondt PD, Cosyns P, De Broe ME: Hipozincemia in depression. J Affect Disord, 1994, 31, 135-140.

12. Maes M, Vandoolaeghe E, Neels H, Demedts P, Wauters A, Meltzer HY, Altamura C, Desnyder R: Lower serum zinc in major depression is a sensitive marker of treatment resistance and of the immune/inflammatory response in that illness, Biol Psychiatry, 1997, 42, 49-358.

13. McLoughlin IJ, Hodge JS: Zinc in depressive disorder. Acta Psychiatr Scand, 1990, 82, 451-453.

14. Moghaddam B, Bolinao ML, Stein-Behrens B, Sapolsky R: Glucocorticoids mediate the stress-induced extracellular accumulation of glutamate. Brain Res, 1994, 655, 251-254. 
15. Nowak G, Siwek M, Dudek D, Zięba A, Pilc A: Effect of zinc supplementation on antidepressant therapy in unipolar depression: a preliminary placebo-controlled study, Pol J Pharmacol, 2003, 55, 1143-1147.

16. Nowak G, Szewczyk B, Pilc A: Zinc and depression. An update. Pharmacol Rep, 2005, 57, 713-718.

17. Nowak G, Szewczyk B, Wierońska JM, Brański P, Pałucha A, Pilc A, Sadlik K, Piekoszewski W: Antidepressant-like effects of acute and chronic treatment with zinc in forced swim test and olfactory bulbectomy model in rats. Brain Res Bull, 2003, 61, 159-164.

18. Opoka W, Sowa-Kućma M, Stachowicz K, Ostachowicz B, Szlósarczyk M, Stypuła A, Młyniec K et al.: Early life time zinc supplementation protects zinc-deficient dietinduced alterations. Pharmacol Rep, 2010, 62, 1211-1217.

19. Paoletti P, Ascher P, Neyton J: High-affinity zinc inhibition of NMDA NR1-NR2 receptors. J Neurosci, 1997, 17, 5711-5725

20. Rosa AO, Lin J, Calixto JB, Santos ARS, Rodrigues ALS: Involvement of NMDA receptors and L-argininenitric oxide pathway in the antidepressant-like effects of zinc in mice. Behav Brain Res, 2003, 144, 87-93.

21. Sawada T, Yokoi K: Effect of zinc supplementation on mood states in young women: a pilot study. Eur J Nutr, 2010, 64, 331-333.

22. Sensi SL, Paoletti P, Bush AI, Sekler I: Zinc in the physiology and pathology of the CNS. Nat Rev Neurosci, 2009, 10, 780-791.

23. Siwek M, Dudek D, Paul JA, Sowa-Kućma M, Zięba A, Popik P, Pilc A, Nowak G: Zinc supplementation augments efficacy of imipramine in treatment resistant patients: A double blind, placebo-controlled study. J Affect Disord, 2009, 118, 187-195.

24. Siwek M, Dudek D, Schlegel-Zawadzka M, Morawska A, Piekoszewski W, Opoka W, Zięba A et al.: Serum zimc level in depressed patients during zinc supplementation of imipramine treatment. J Affect Disord, 2010, 126, 447-452.

25. Skolnick P, Layer RT, Popik P, Nowak G, Paul IA, Trullas R: Adaptation of N-methyl-D-aspartate (NMDA) receptors following antidepressant treatment: implications for the pharmacotherapy of depression, Pharmacopsychiatry, 1996, 29, 23-26.

26. Skolnick P, Legutko B, Li X, Bymaster F: Current perspectives on the development of non-biogenic amine based antidepressants, Pharmacol Res, 2001, 43, 411-423.

27. Skolnick P, Popik P, Trullas R: Glutamate-based antidepressants: 20 years on. Trends Pharmacol Sci, 2009, 30, 563-569.

28. Skolnick P, Popik P, Trullas R: N-Methyl-D-Aspartate (NMDA) Antagonists for the Treatment of Depression, in Glutamate-based Therapies for Psychiatric Disorders. Ed. Skolnick P., Springer Basel AG, 2010, 1-20.

29. Sowa-Kućma M, Legutko B, Szewczyk B, Novak K, Znojek P, Poleszak E, Papp M et al.: Antidepressant-like activity of zinc: further behavioural and molecular evidence. J Neural Transm, 2008, 115, 1621-1628.

30. Steru L, Chermat R, Thierry B, Simon P: The tail suspension test: a new method for screening antidepressants in mice. Psychopharmacology, 1985, 85, 367-370.
31. Stokes PE: The potential role of excessive cortisol induced by HPA hyperfunction in the pathogenesis of depression. Eur Neuropsychopharmacol, 1995, 5, 77-82.

32. Szewczyk B, Brański P, Wierońska JM, Pałucha A, Pilc A, Nowak G: Interaction of zinc with antidepressants in the forced swimming test in mice. Pol J Pharmacol, 2002, 54, 681-685.

33. Szewczyk B, Kubera M, Nowak G: The role of zinc in neurodegenerative inflammatory pathways in depression, Prog Neuropsychopharmacol Biol Psychiatry, 2011, 35, 693-701.

34. Szewczyk B, Nowak G: Mechanisms contributing to antidepressant zinc actions. Pol J Pharmacol, 2002, 54, 587-592.

35. Szewczyk B, Poleszak E, Pilc A, Nowak G: Ionic glutamate modulators in depression (zinc and magnesium). In: Glutamate-based Therapies for Psychiatric Disorders, Ed. Skolnick P, Springer Basel AG, 2010, 21-38.

36. Szewczyk B, Poleszak E, Sowa-Kućma M, Siwek M, Dudek D, Ryszewska-Pokraśniewicz B, RadziwońZaleska $M$ et al.: Antidepressant activity of zinc and magnesium in view of the current hypotheses of antidepressant action. Pharmacol Rep, 2008, 60, 588-599.

37. Szewczyk B, Poleszak E, Wlaź P, Wróbel A, Blicharska E, Cichy A, Dybała M et al.: The involvement of serotonergic system in the antidepressant effect of zinc in the forced swim test: Prog Neuropsychopharmacol Biol Psychiatry, 2009, 33, 323-329.

38. Takeda A: Movement of zinc and its functional significance in the brain. Brain Res Rev, 2000, 34, 137-148.

39. Takeda A, Hirate M, Tamano H, Oku N: Release of glutamate and GABA in the hippocampus under zinc deficiency. J Neurosci Res, 2003, 72, 537-542.

40. Takeda A, Itoh H, Tamano H, Oku N: Responsiveness to kainate in young rats after 2-week zinc deprivation. BioMetals, 2006, 19, 565-572.

41. Takeda A, Tamano H: Insight into zinc signaling from dietary zinc deficiency. Brain Res Rev, 2009, 62, 33-44.

42. Takeda A, Tamano H, Kan F, Itoh H, Oku N: Anxietylike behavior of young rats after 2-week zinc deprivation. Behav Brain Res, 2007, 177, 1-6.

43. Takeda A, Yamada K, Minami A, Nagano T, Oku N: Enhanced excitability of hippocampal mossy fibers and CA3 neurons under dietary zinc deficiency. Epilepsy Res, 2005, 63, 77-84.

44. Tamano H, Kan F, Kawamura M, Oku N, Takeda A: Behavior in the forced swim test and neurochemical changes In the hippocampus in young rats after 2-week zinc deprivation. Neurochem Int, 2009, 55, 536-541.

45. Tassabehij MN, Corniola RS, Alshingiti A, Levenson $\mathrm{CW}$ : Zinc deficiency induces depression-like symptoms in adult rats. Physiol Behav, 2008, 95, 365-369.

46. Valee BL: The function of metallothionein. Neurochem Int, 1995, 27, 23-33.

47. Virgin CE, Ha TP, Packan DR, Tombaugh GC, Yang SH, Horner HC, Sapolsky RM: Glucocorticoids inhibit glucose transport and glutamate uptake in hippocampal astrocytes: implications for glucocorticoid neurotoxicity. J Neurochem, 1991, 57, 1422-1428. 
48. Watanabe M, Tamano H, Kikuchi T, Takeda A: Susceptibility to stress in young rats after 2-week zinc deprivation, Neurochem Int, 2010, 56, 410-416.

49. Whittle N, Lubec G, Singewald N: Zinc deficiency induces enhanced depression-like behaviour and altered limbic activation reversed by antidepressant treatment in mice. Amino Acids, 2009, 36, 147-158.

50. Wójcik J, Dudek D, Schlegel-Zawadzka M, Grabowska M, Marcinek A, Florek E, Piekoszewski W et al.: Antepartum/postpartum depressive symptoms and serum zinc and magnesium levels. Pharmacol Rep, 2006, 58, 571-576.

51. Yeiser EC, Lerant AA, Casto RM, Levenson CW:

Free zinc increases at the site of injury after cortical stab wounds in mature but not immature rat brain. Neurosci Lett, 1999, 277, 75-78.

52. Young EA, Altemus M, Lopez JF, Kocsis JH, Schatzberg $\mathrm{AF}$, deBattista Ch, Zubieta J-K: HPA axis activation in major depression and response to fluoxetine: a pilot study. Psychoneuroendocrinology, 2004, 29, 1189-1204.

Received: July 10, 2011; in the revised form: November 8, 2011; accepted: November 21, 2011. 